\title{
Marek Laziński
}

\section{CZASOWNIKI NIEKONIECZNEGO SKUTKU NA TLE CZASOWNIKÓW TELICZNYCH. PRÓBA CHARAKTERYSTYKI ${ }^{1}$}

Opozycje aspektowe czasowników niekoniecznego skutku - to część opozycji telicznych, $w$ których $z$ zaprzeczenia rematycznego zdania $z$ czasownikiem $d k$ wnioskujemy, na zasadzie presupozycji, że prawdziwe jest zdanie twierdzace z czasownikiem ndk. Semantycznie można określić te czasowniki jako konatywne, czyli oznaczajace próbę, ale granice konatywów sa szersze. Presupozycja zaprzeczonych konatywów jest ogólniejsza od opozycji aspektowych niekoniecznego skutku. W presupozycji zaprzeczonych czasowników konatywnych sensu stricto próba działania nie musi być nazwana odpowiednim czasownikiem ndk z pary aspektowej. W grupie czasowników konatywnych sensu largo presuponowana nie jest próba, leczy tylko oczekiwanie nadawcy, że akcja zostanie podjęta. Opozycje niekoniecznego skutku sq specyficzne dla języka, tak jak specyficzne sq zasady uzycia czasownika ndk $w$ znaczeniu ogólnofaktycznym. Presupozycja próby dla konatywów jest bardziej uniwersalna. Powyższa próba charakterystyki tej grupy dotyczy tylko języka polskiego.

Stowa kluczowe: czasowniki konatywne, czasowniki niekoniecznego skutku, presupozycja, próba, oczekiwanie.

Powszechnie przyjmowane kryterium parzystości aspektowej (Маслов, 1948) opiera się na znaczeniu trywialnym, czyli iteratywnym lub praesens historicum czasownika ndk, który w tym znaczeniu może oznaczać to samo zdarzenie, co czasownik dk. Tak samo dobrą parę aspektową tworzą więc czasowniki (a właściwie predykaty) teliczne accomplishment pisać - napisać i nieteliczne achievement strzelić: strzelać. Jednak to właśnie opozycje pierwszego typu tworzą prototypowe centrum opozycji aspektowej, są najczęściej omawiane w literaturze oraz jako pierwsze wprowadzane $\mathrm{w}$ gramatykach języków słowiańskich i podręcznikach tych języków jako obcych.

Niniejszy artykuł poświęcimy szczególnej grupie predykatów telicznych, w której naturalny kierunek implikacji od procesu lub działania prowadzącego do zmiany rzeczywistości do zdarzenia, czyli tej właśnie zmiany, wydaje się zaburzony. Zdarzenie traktuję jako pojęcie pierwotne definicyjne dla aspektu dk. Istotą zdarzenia jest zmiana rzeczywistości, ale zdarzenie może obejmować nie tylko zmianę, lecz i prowadzący do niej proces (pojęcia proces sensu largo będę używać $\mathrm{w}$ znaczeniu 'proces sensu stricto - niekontrolowany - lub działanie -

\footnotetext{
${ }^{1}$ Artykuł powstał w ramach grantu Beethoven II, nr projektu NCN: 2016/23/G/HS2/00922.

(C) Marek Eaziński, 2020

DOI: $10.24025 / 2707-0573.2(3) .2020 .219187$
} 
kontrolowane'). Zdarzeniem możemy więc nazwać moment ukończenia listu, dzielący czas na okres, w którym list nie istniał (w całości), oraz taki okres, w którym list istnieje. Zdarzeniem jest także zmiana stanu wraz z poprzedzającym działaniem (napisałem list w pół godziny). Nie wchodzę w tym miejscu w żywą $\mathrm{w}$ aspektologii dyskusję na temat istnienia zdarzeń niezmiennostanowych (postulują je m.in. Bogusławski, 2004; Karolak, 2005), zakładam, że takie zdarzenia jak „mrugnąć” także oznaczają zmianę (zamknięcie powieki), tyle że jej efekty są anulowane w czasie znacznie krótszym niż czas odniesienia obserwacji ludzkiej, rozumiany jako ,psychiczne teraz” i równy mniej więcej czasowi potrzebnemu na wypowiedzenie zdania.

Charakterystyka czasowników niekoniecznego skutku (konatywnych): implikacja i presupozycja. Interesuje nas grupa czasowników dk oznaczających zdarzenia, które są zapowiadane nie wprost przez odpowiednie procesy oznaczane czasownikami ndk, np. ratować: uratować, przekonywać: przekonać, zdawać: zdać (egzamin). Spróbujmy najpierw opisać specyfikę opozycji aspektowych w tej grupie, a następnie wyznaczyć jej granice leksykalne. Nasza analiza dotyczy polszczyzny, ale ważnym punktem odniesienia będzie język rosyjski - także ze względu na osiągnięcia teoretyczne aspektologii rosyjskiej.

Padučeva nazywa tego typu akcje konatywami (Paducheva, 2008, s. 10). Działanie jest w konatywach tylko presupozycją, asercja obejmuje tylko rezultat działania. Będziemy stosować dłuższy termin czasowniki/opozycje niekoniecznego skutku oraz krótszy konatywy wymiennie, pamiętając, że drugi z nich ma szerszy, uniwersalny zakres, odnosi się do semantyki dowolnej akcji, a pierwszy ma charakteryzować specyficzne opozycje aspektowe.

Glovinskaja włącza takie czasowniki do III typu opozycji aspektowych telicznych z eksplikacją czasownika ndk „действовать с иелью” - „działać w celu” i eksplikacją czasownika dk „достичь цели” - „osiągnąć cel” (Glovinskaya, 1982, s. 89-91). Przykłady czasowników z tej grupy to: peuamb: peuumb, доказывать: доказать.

Jak wiadomo najwyraźniejszym testem wydzielenia presupozycji jest zaprzeczenie asercji. Zdania:

(1) Film mi się nie podoba oraz

(2) Film mi się podoba

- są sensowne pod warunkiem, że widziałem ten film.

Warunkiem sensowności zdań:

(3) Rozwiąałem zadanie. Udowodniłem swoja racje oraz

(4) Nie rozwiazałem zadania. Nie udowodnitem swojej racji

- powinno być to, że je rozwiązywałem, czyli próbowałem rozwiązać - działałem w celu rozwiązania zadania. $Z$ kolei zdanie:

(5) Nie rozwiazywatem zadania

znaczy, że w ogóle nie podjąłem próby.

Padučeva (2008) zwraca uwagę, że zaprzeczone konatywy ndk w znaczeniu ogólnofaktycznym nie odnoszą się do tego samego zdarzenia (właściwie jego braku) co czasownik dk:

(6) Nie rozwiązywałem zadania - nie równa się - Nie rozwiązałem.

W polskiej aspektologii klasyfikację Głowińskiej przyswoił Holvoet (1989) o opozycjach tego typu pisali też Bogusławski i Łaziński (2020). Holvoet podaje przykłady namawiać: namówić oraz ratować: uratować.

(7) Nie namówiłem go na tę wycieczkę-presuponuje

(8) Namawiałem go na tę wycieczkę (Holvoet, 1989, s. 99). 
Zdanie (9) Lekarz nie uratowat chorego ,jest niewłaściwe, jeśli mówiący chce zaznaczyć, że nie miało miejsca samo działanie w celu uratowania chorego" (Holvoet, 1989, s. 100).

Zwróćmy uwagę, że presupozycja zdania (9) została podana w innej formie, niż zdanie (8) jako presupozycja (7). Zastanówmy się, co znaczy w tym wypadku miało miejsce dziatanie $w$ celu uratowania chorego i dlaczego to sformułowanie nie jest równoznaczne z konstrukcją ratowat chorego.

Autor nie proponuje czasownika ndk ratowat, po pierwsze dlatego, że ten nie ma w języku polskim znaczenia aktualnego procesywnego. Ale nie tylko dlatego. Podstawmy w miejsce lekarza inny podmiot, aby nie ograniczać znaczenia ratować do leczenia. Weźmy zdanie

(10) Przechodzień nie uratowat tonacego.

Warunkiem sensowności tego zdania niekoniecznie jest sytuacja, którą nazwiemy Przechodzień ratowat tonacego.

Sytuacja ta obejmuje takie zdarzenia jak: przechodzień skoczył do wody, podał tonącemu linę lub inne. Jednak przechodzień mógł nie uratować tonącego, bo go nie zauważył. Presupozycję zdania (10) trzeba sformułować ogólniej: nadawca oczekiwał, że w tej sytuacji tonący zostanie uratowany, ale niekoniecznie oznacza to aktywność przechodnia.

Poniżej wybrane przykłady konstrukcji $X$ nie uratowat z Narodowego Korpusu Języka Polskiego (nkjp.pl), w których na pewno nie oczekujemy presupozycji 'X ratował' (ograniczam się do sytuacji obejmujących działania osób fizyczne, nieabstrakcyjne).

(11) Janusz, buda ci się pali - alarmowat znajomy z Lęknicy. $220 \mathrm{~km}$ $z$ Poznania pokonat $w$ dwie godziny. Kiedy dojechat, palita się już jego trzecia, ostatnia buda. Niczego nie uratowat (Gazeta Wyborcza).

(12) I kiedy wydawało im się, że wszystko się ułożyło, Francuz zachorowat. Zdiagnozowano mu guza w plucach. Walczyła o niego. Ale nie uratowała. (R. Grzela, Bądź moim Bogiem).

(13) A więc, jak Jezus [...] - jak On mógł zginąć na krzyżu? Dlaczego Bóg, który jest wszechmocny, to dopuścit? Dlaczego Go nie uratowat od śmierci? (M. Maliński, Zagadki ewangeliczne).

W powyższych sytuacjach mogliśmy oczekiwać, że właściciel magazynów zdąży dojechać do pożaru i uratuje towar, że żona uratuje życie męża, organizując jego leczenie, że Bóg uratuje swego syna. Nie możemy jednak powiedzieć, że właściciel, żona czy Bóg kogoś albo coś ratowali.

Oczekiwanie akcji oznaczonej czasownikiem ndk jako warunek sensowności użycia zaprzeczonego czasownika $\mathrm{dk}$ można porównać $\mathrm{z}$ oczekiwaniem warunkującym użycie zaprzeczonego lub niezaprzeczonego czasownika dk w kontraście do znaczenia ogólnofaktycznego czasownika ndk.

(14) Przeczytateś Biegunów albo wobec

(15) Nie przeczytałeś Biegunów

(16) Czytałeś Biegunów albo

(17) Nie czytałeś Biegunów.

Czasowniki dk odnoszą się do sytuacji, w której przeczytanie Biegunów jest oczekiwane lub wymagane, wchodzi w skład wspólnej wiedzy kontekstowej wspólnej nadawcy i odbiorcy (por. Rassudova, 1968, s. 20; Israeli, 1996, p. 18-19).

Kolejny, dłuższy cytat pochodzi z wypowiedzi Władysława Bartoszewskiego:

(18) Ratowaliśmy, zaopatrując ludzi $w$ dokumenty, zapomogi finansowe, znajdując lokale, ułatwiając powrót do życia [...], ale ilu uratowaliśmy? Ot, widzi 
pan, sprawa jednej litery stwarza ogromna różnicę. Ratować $i$ uratować! Ratowaliśmy kilkadziesiąt więcej razy ludzi niż uratowaliśmy. Przez moje ręce przeszło kilkaset dobrze zrobionych dokumentów, kennkart, kart prac, różnych dokumentów, które ułatwiaty życie. Ułatwiały, ale nie gwarantowaty przeżycia! Więc, dla mnie jest ważne, żeby odróżniać słowo "ratować" od słowa ,uratować" (M. Komar, Wtadystaw Bartoszewski. Wywiad rzeka).

Opozycja ratować: uratować opiera się na klasycznej implikacji telicznej: „ratowaliśmy, ale nie wiemy, czy uratowaliśmy”. Fragment wypowiedzi „ratowaliśmy kilkadziesiąt więcej razy ludzi niż uratowaliśmy” można by eksplikować „nie uratowaliśmy, choć ratowaliśmy”. Po pierwsze jednak możliwa jest tu interpretacja iteratywna ratowania kolejno wielu ludzi, po drugie cała wypowiedź - to użycie specyficzne języka, swoista gra językowa. Ratowaliśmy nie oznacza, jak w zdaniu (9) natychmiastowego działania fizycznego w obliczu zagrożenia w danym momencie, oznacza zespół planowych działań ${ }^{2}$.

Eksplikacja czasownika uratować zawiera element 'udało się' mimo niepewności co do skutku działania. Ten sam element obecny jest w eksplikacji innych czasowników niekoniecznego skutku.

Ograniczenia presupozycji przeczenia. Zanim przejdziemy do wyznaczenia granic grupy czasowników konatywnych, zwróćmy uwagę na jeszcze inne ograniczenia testu presupozycji przeczenia, podanego w zdaniu (8). Pierwszym ograniczeniem jest złagodzenie presupozycji z działania tego samego podmiotu na oczekiwanie takiego działania (por. wyżej).

Drugie ograniczenie wiąże się z obiektem działania. Nie można przekonać kogoś częściowo do wyjazdu, dlatego skutek przekonywania jest albo zupełny, albo żaden. Można jednak przekonać kogoś częściowo do jakiejś koncepcji czy do filmów Woody'ego Allena (niektórych). Podobnie jest z rozwiązaniem problemów i zadań. Jeśli uczeń rozwiązywał zadanie $\mathrm{z}$ wynikiem liczbowym, to albo je rozwiązał, albo nie. Jeśli jednak obiekt jest podzielny, możemy wnioskować o częściowym skutku.

Ze zdania:

(19) Nie rozwiazal tego zadania

zawsze wynika, że:

(20) Rozwiazywat to zadanie - lub na mocy złagodzenia warunku oczekujemy, że powinien to zrobić.

Jeśli zadanie jest krzyżówką, to ze zdania: wynika

(21) Nie rozwiąal krzyżówki

(22) Rozwiazywat krzyżówkę, ale też ze zdania (22) wynika, że przynajmniej częściowo ją rozwiązał.

Trzecie ograniczenie presupozycji wynika $\mathrm{z}$ charakteru przeczenia. Presupozycja typu (8) jest oczywiście warunkowana ogólnym, rematycznym zakresem przeczenia - bezkontekstowym zaprzeczeniem pytania o rozstrzygnięcie. Zdania z negacją szczegółową, częściową:

(23) To nie przechodzień uratowat tonacego i

(24) To nie tonacego uratowat przechodzień, tylko rannego $w$ wypadku nie presuponują, że przechodzień ratował tonącego ani, że tego od niego oczekiwano. Te zdania mogą mieć postać identyczną jak zdanie (10). Przechodzień nie uratował tonącego, a różnicy zakresu przeczenia może sygnalizować akcent.

${ }^{2}$ Chodzi o działania Rady Pomocy Żydom polskiego Państwa Podziemnego, której Bartoszewski był członkiem. 
Granice grupy czasowników konatywnych. Spróbujmy teraz zaproponować granice interesującej nas grupy. Znaczenie czasownika dk można eksplikować z elementem 'udało się': udało się zdać egzamin, uratować tonącego, przekonać Marysię do wyjazdu. Znaczenie czasownika ndk można z kolei eksplikować z elementem próbować (działać w celu).

Aby znaleźć najczęstsze czasowniki konatywne, w Narodowym Korpusie Języka Polskiego (nkljp.pl) wyszukano 240 bezokoliczników dk w konstrukcji „komuś + (nie) udało się + bezokolicznik czasownika dk”. Poniżej uwzględniono 69 czasowników o frekwencji co najmniej 5 , z czego 10 czasowników o frekwencji co najmniej 25 poddaliśmy dokładniejszej analizie. W wyniku tej analizy wyznaczyliśmy 5 grup semantyczno-aspektowych i przydzieliliśmy do nich pozostałe czasowniki. Dla uproszczenia traktujemy wszystkie czasowniki jako niezwrotne (bez się) i bierzemy pod uwagę jedynie podstawowe znaczenie niemetaforyczne (jest to szczególnie ważne przy wieloznacznych czasownikach ruchu). Obok czasownika dk wyszukanego w korpusie podajemy odpowiednik ndk.

- Zatrzymać: zatrzymywać (50 wystąpień czasownika dk w tej konstrukcji). Wydaje się, że ze zdania Nie zatrzymatem go $w$ domu wynika, że próbowałem zatrzymać, ale nie wyrażam tej próby w naturalny sposób czasownikiem zatrzymywatem. $\mathrm{Z}$ drugiej strony, wysoką frekwencję ma konstrukcja w czasie ter. Nie zatrzymuję cię/pani/pana, wypowiedziana do gościa, który się spieszy (46 wystąpień w NKJP).

- Uciec: uciekać (47 wystąpień). Ze zdania $X$ nie uciekt wynika, że próbował uciec. Presupozycję zaciera fakt, że czasownik dk odnosi się albo do opuszczenia miejsca odosobnienia (uciekł z więzienia), albo do skutecznej ucieczki, czyli znalezienia się poza zasięgiem pogoni. W drugim znaczeniu prawdziwa jest zarówno presupozycja nie uciekt, czyli uciekat, ale też zwykła implikacja teliczna uciekat $i$ w końcu uciekt.

- Bliskoznaczne czasowniki zdobyć (39): zdobywać, odzyskać (31): odzyskiwać oraz uzyskać (30): uzyskiwać w czasie przeszłym presuponują próbę, ale nie nazwiemy tej próby czasownikiem ndk $X$ zdobywat ani $X$ odzyskiwat. Podobna jest presupozycja czasownika ustalić (31): ustalać.

- Stworzyć (27): tworzyć: stwarzać (trójka aspektowa) zaprzeczone w czasie przeszłym nie presuponuje, że ktoś próbował stworzyć ani tym bardziej, że stwarzał czy tworzył. Między czasownikiem ndk i dk zachodzi prosta implikacja teliczna.

- Kolejnemu czasownikowi na liście: uratować (25): ratować poświęciliśmy już sporo uwagi wyżej.

- Czasowniki znaleźć (25): znajdować i dotrzeć (25): docierać nie tworzą opozycji telicznych z odpowiednikami ndk znajdować i docierać, a wiec te czasowniki nie mogą być presuponowane przez zaprzeczenie czasownika ndk. Ze zdania X nie znalazł kluczy wynika, że ich szukał. Szukać i znaleźć tworzą semantyczną opozycję teliczną, ale nie parę aspektową).

$\mathrm{Na}$ podstawie dotychczasowych analiz można wydzielić pięć grup czasowników, w tym trzy pierwsze obejmujące konatywy sensu stricto i sensu largo. Pozostałe czasowniki z listy NKJP przydzielamy do tych grup na podstawie podobnych testów semantycznych, co powyżej, ale bez ich przytaczania w tekście:

1) Pierwsza grupa - to opozycje konatywne sensu stricto, w których zaprzeczony czasownik $\mathrm{dk}$ presuponuje wprost niezaprzeczony czasownik ndk (typ przekonywać-przekonać):

namówić, przekonać (por. wyżej), sforsować, ugasić, uzbierać, wynegocjować, zebrać, zgromadzić, zrealizować. 
Tylko dla tej grupy rezerwujemy nazwę opozycje niekoniecznego skutku. Znalazły się tu czasowniki o wspólnym znaczeniu przekonywania, gromadzenia oraz izolowanych akcji fizycznych nakierowanych na ostateczne zwycięstwo (ugasić, sforsować).

Podobne pole semantyczne zakreśla Glovinskaja (1982) dla opozycji działać w celu: osiągnąć cel. Autorka wymienia przykłady czasowników przekonywania i podejmowania decyzji - доказать: доказывать, заставить: заставлять, решить: решать oraz akcji fizycznych nakierowanych na cel.

Warto w tym miejscu zwrócić uwagę, że relacja presupozycji wewnątrz pary aspektowej jest specyficzna dla języka. W polszczyźnie ze zdania Chłopiec nie złapat motyla nie wynika, że chłopiec łapał motyla, lecz tylko, że próbował go złapać. Podobnie specyficzne jest użycie czasownika ndk w znaczeniu ogólnofaktycznym. O międzysłowiańskich różnicach w stosowaniu czasowników ndk w znaczeniu ogólnofaktycznym por. np. Dickey (2000).

W grupie czasowników gromadzenia presupozycja zaprzeczonego czasownika dk wynika z parametrycznego charakteru akcji. Z faktu, że

(25) Jan nie zgromadzit wystarczajacej sumy pieniędzy

możemy się domyślać, że

(26) Jan gromadzit pieniądze,

ale obiekty gromadzenia w obu predykacjach nie są identyczne (por. przykład 22 rozwiąywat krzyżówkę).

2) Opozycje konatywne sensu stricto, w których zaprzeczony czasownik dk presuponuje znaczenie próby, ale niewyrażone odpowiednim czasownikiem ndk (typ zdobyć - zdobywać):

dojść (czasownik ruchu), doprowadzić, odnaleźć, opanować, osiagnąć, pokonać, porozmawiać, pozyskać (por. wyżej zdobyć), przeprowadzić, ukryć, uniknąc, uspokoić, utrzymać, utrzymać się, wprowadzić, wyciagnać, wydostać, wygrać, wypracować, wyprowadzić, wyrwać, wywalczyć, załatwić, zbiec (por. wyżej uciec), złapać, zorganizować.

Ta grupa jest najliczniejsza wśród konatywów. Należą do niej czasowniki oznaczające ucieczkę, ogólne określenia realizacji celu (osiagnąć, pozyskać, załatwić), zwycięstwa, ukrycia i uniknięcia czegoś oraz czasowniki ruchu przechodnie i nieprzechodnie. Część zaprzeczonych czasowników dk nie presuponuje odpowiednich czasowników ndk, ponieważ próba nazywana jest bardziej ogólnie, niektóre czasowniki ndk nie są teliczne i nie mogą nazywać akcji nakierowanej na cel.

3) Opozycje konatywne sensu largo, w których zaprzeczony czasownik dk presuponuje tylko oczekiwanie nadawcy i/lub odbiorcy, że próba zostanie podjęta (typ ratować - uratować):

dostać, dowiedzieć się, odtworzyć, poprawić, porozmawiać, przetrwać, przeżyć, przywrócić, zabezpieczyć, zaprosić, zniwelować.

Do tej grupy należą przede wszystkim nazwy sytuacji niezależnych od woli agensa (przeżyć, dowiedzieć się), a także takich, które nie zależą od woli nadawcy, ale są przez niego pożądane (zaprosić). Interesujący jest casus jedynego w tej grupie perfectivum tantum: porozmawiać.

Mówimy:

(27) Jan nie porozmawiat $z$ dyrektorem

jeśli oczekiwaliśmy takiej rozmowy. Absolutnie nie wynika $\mathrm{z}$ tego, że Jan rozmawiał z dyrektorem, ponieważ rozmawiać i porozmawiać nie tworzą pary aspektowej. 
Pozostałe czasowniki dk występujące w korpusie w kontekście „(nie) udało się + bezokolicznik dk" nie tworzą opozycji konatywnych nawet sensu largo. Można je podzielić na dwie grupy:

4) Klasyczne opozycje teliczne stopniowalne bez specjalnej presupozycji zaprzeczonego czasownika dk (typ pisać - napisać):

zbudować, zrobić.

5) Opozycje nieteliczne, a zatem i niekonatywne bez specjalnej presupozycji zaprzeczonego czasownika dk (typ mrugać - mrugnać):

połaczyć, wyjść, sprzedać, nawiazać, uwolnić, ściagnać (ruch fizyczny), przekazać, dokonać, odnieść (ruch fizyczny), kupić, strzelić, wybudować, zmniejszyć.

\section{Bibliografia}

Boguławski, A. (2004). Apekt i negacja, Warszawa: Wydawnictwo Takt.

Dickey, S. M. (2000). Parameters of the Slavic Aspect, Stanford: CSLI.

Holvoet, A., (1989). Aspekt a modalność w języku polskim na tle ogólnostowiańskim, Wrocław-Warszawa: Zakład Narodowy im. Ossolińskich.

Israeli, A. (1996). Discourse analysis of Russian aspect: accent on creativity. Journal of Slavic Linguistic. 4 (1). 8-49.

Karolak, S. (2005). Semantyka i struktura aspektu w językach naturalnych, Kielce: Wyższa Szkoła Umiejętności.

Łaziński, M. (2020). Wyktady o aspekcie polskiego czasownika, Warszawa: Wyd-wo Uniwersytetu Warszawskiego.

Glovinskaya, M. Ya. (1982). Semanticheskie tipy vidovyh protivopostavlenij russkogo glagola. Moskva: Nauka.

Maslov, Yu. S. (1948). Vid i leksicheskoe znachenie glagola $\mathrm{v}$ sovremennom russkom literaturnom yazyke. Izvestiya AN SSSR. Otdelenie literatury i yazyka. T. 7 (4), 303316.

Paducheva, E. V. (2008). Imperfektiv otricaniya v russkom yazyke. Voprosy yazykoznaniya. $3,3-21$.

Rassudova, O. P. (1968). Upotreblenie vidov glagola v russkom yazyke. Moskva: Izd. MGU.

\section{Резюме}

\section{Марек Лазінські}

\section{ДІЕСЛОВА ЇМОВІРНІСНОГО РЕЗУЛЬТАТУ НА ФОНІ ТЕРМІНАТИВНИХ ДІЕСЛІВ. СПРОБА ХАРАКТЕРИСТИКИ}

Постановка проблеми. Аспектуальні опозиції дієслів їмовірнісного результату - це специфічні опозиції, у яких, виходячи із рематичних заперечних тверджень 3 дієсловами доконаного виду, ми можемо зробити висновок про істинність речень з дієсловами недоконаного виду. Наприклад, пропозиція „Nie namówitem go na wycieczkę" 'Я не умовив його піти на екскурсію' має сенс лише у тому разі, якщо ми можемо додати „Namawiatem go na wycieczke” 'Я умовляв його піти на екскурсію’, де значення імперфективу означає «намагатися». Подібні дієслова Падучева (2008) називає «конативами», вони утворюють тип III серед 4-х семантичних типів видових опозицій, описаних Гловінською (1982). Основне значення недоконаного виду в цьому типі опозиції - «мати на меті», доконаного виду - «досягти мети». Цей семантичний тип недоконаного виду протиставлений найпоширенішому імперфективному типу I, що виражає поступове досягнення мети, яка частково досягається на кожному етапі дії. 
Мета статті. Охарактеризувати особливості дієслів їмовірнісного результату на фоні термінативних дієслів.

Методи та основні результати дослідження. Термін «дієслова їмовірнісного результату» вважається вужчим, ніж «конативи», оскільки він обмежений аспектуальними опозиціями, де спроба, як частина пресупозиції заперечного перфектива, виражена за допомогою відповідного імперфективного партнера. Інші конативи виражають спробу іншими способами, напр., 3 дієсловом próbować 'пробувати' та ,próbowat mnie namówic'. Семантика перфективних конативів містить елемент "udało się" 'вдалося'. У групі конативів sensu largo пресупозиція не містить спроби дії, виражену перфективом, а лише сподівання мовця на таку дію. Пресупозиція спроби або очікування у конативах належить до загального, рематичного заперечення дієслова доконаного виду і до неподільного об'єкту. Для характеристики лексичних груп дієслів, що належать до вищезазначених класів, найпоширеніші інфінітиви доконаного виду після «иdało się» були знайдені в Національному корпусі польської мови. Перша група конативів sensu stricto, тобто дієслова їмовірнісного результату, містить насамперед дієслова вольового мовлення, напр. Namówić. Подібні дісслова в російській мові належать до видової опозиції ІІІ типу Гловінської, проте прямої відповідності між польською та російською мовами не спостерігаємо. Друга і найбільша група конативів sensu stricto без імперфективного аспектуального партнера у пресупозиції заперечення перфектива містить насамперед дієслова зі значенням «рятуватися»: исіес, «виграти»: напр. zwyciężyc, або загальне значення «успіх», а також деякі перехідні дієслова руху. Третя група конативів sensu largo з пресупозицією «очікування» називає ситуації, які не контролює агенс, напр. przeżyć 'вижити' або uratować 'рятувати своє життя'.

Висновки і перспективи. Видова опозиція їмовірнісного результату $\epsilon$ специфічною для конкретної мови, оскільки специфічним $є$ використання дієслів недоконаного виду у загальнофактичному значенні. Наведений вище аналіз обмежений польською мовою. Характер конативних дієслів можна трактувати як універсальний.

Ключові слова: конативні дієслова, дієслова їмовірнісного результату, пресупозиція, спроба, очікування.

\section{Abstract}

\section{Marek Laziński}

\section{VERBS OF AN UNNECESSARY RESULT AGAINST THE BACKGROUND OF TELIC VERBS}

Background. Aspectual oppositions of verbs of an unnecessary result are noted for a special presupposition of the negated perfect verb which is conditioned by the truthfullnes of the un-negated imperfective verbs. For example, sentence "Nie namówiłem go na wycieczkę" 'I did not pesuade him to go for excursion' has sense only in case we can add "Namawiałem go na wycieczkę" 'I tried to persuade him to go for excursion', where the meaning of the imperfective is 'to attempt'. Similar verbs are called "conatives" by Padučeva (2008), they form Type III in the framework of the 4 semantic types of telic oppositions described by Glovinskaya

\footnotetext{
${ }^{3}$ Artykuł powstał w ramach grantu Beethoven II, nr projektu NCN: 2016/23/G/HS2/00922.
} 
(1982). The explication of the imperfective in this type of opposition is 'to pursue a goal' the explication of the perfective is 'to achieve the goal'. The explication of the imperfective is opposed to the most common type of imperfectives of the Type I which expresses a graduate pursuit of the goal, where the goal is partially achieved at every stage of the action.

Purpose. The purpose of this article is to study the specifics of verbs of an unnecessary result against the background of telic verbs.

Methods and Results. The term "verbs of an unnecessary result" is considered to be narrower than "conatives", since it is restricted to aspectual oppositions, where the attempt, as a part of the presupposition of the negated perfective, is expressed literally with the imperfective partner of the corresponding perfective. Other conatives express the attempt in other ways, e.g. with the verb próbować 'to try' and the perfective „próbował mnie namówić'. The explication of perfective conatives comprise the element "udało się" 'sb. managed to'. In the group of conatives sensu largo the presupposition does not comprise an attempt of an action expressed by the perfective, but only the speaker's expectation for such action. The attempt or expectation presupposition of conatives refers to a general, rhematic negation of the perfective verb and to an object which is undivided. In order to characterise lexical groups of verbs belonging to the above mentioned classes, the most frequent perfective infinitives following 'udało się' have been found in the National Corpus of Polish. The first group of conatives sensu stricto, that is, the verbs of an unnecessary result, comprises first of all volitive speech act verbs, e.g. namówić: Similar verbs in Russian are listed under Glovinska's type III of telic oppositions, but there is no direct correspondence observed between Polish and Russian. The second and the biggest group of conatives sensu stricto without the imperfective aspect partner in the presupposition of the negated perfective contains first of all verbs with the meaning 'to escape': uciec, 'win': eg. zwycięzyć or general meaning 'success', as well as some transitive motion verbs. The third groups of conatives sensu largo with the presupposition "expectation" contains situations that are not controlled by the agent, e.g. przeżyć 'survive' or uratować 'to save one's live'.

Discussion. The oppositions of an unnecessary result are language-specific and depend on specific meanings of the imperfective aspect. The above-presented analysis is restricted to Polish. The nature of conative verbs can be seen as universal. Keywords: conative verbs, verbs of an unnecessary result, presupposition, attempt expectation.

\section{Відомості про автора}

Марек Лазіньскі, доктор хабілітований, професор Вармавського Університету, факультет полоністики (Польща), е-mail: m.lazinski@uw.edu.pl

Marek Laziński, doctor habilitatus, professor, University of Warsaw, Faculty of Polish Studies (Polska),e-mail: m.lazinski@uw.edu.pl

ORCID 0000-0001-5718-4435

Надійшла до редакції 01 грудня 2020 року Прийнято до друку 28 грудня 2020 року 